\title{
A Republic With a Royal CROWN - THE Historical DeVElOPMENT OF THE HOLY CROWN CONCEPT IN THE HUNGARIAN CONSTITUTION
}

\author{
Alexander Szakats*
}

The idea of a Royal Crown personifying a state which is a Republic is an intriguing one. That is the situation of the Republic of Hungary. In this paper Professor Szakats traces the origins of the idea from the early days of Hungary through to its confirmation in 1989. The paper also explores the nature and constitutional implications of the Crown as a legal person.

\section{INTRODUCTION}

After the fall of the Communist regime in 1989 the new democratic government removed from the name of the country the word "Peoples", and now the official designation is "Republic of Hungary". The Soviet style coat of arms was replaced with a new one, which is in fact the old historical emblem which includes the Royal Crown. A Royal Crown usually represents monarchy. Countries where the King abdicated under pressure or ceased ruling as a result of revolution, sometimes in a most cruel manner, obviously did not like, or even hated the monarchy. When such states adopted a republican government, and if and when they introduced a new coat of arms, the Royal Crown as the symbol of oppression is absolutely inconsistent with the new constitution.

Why does a republic retain the Royal Crown in its national emblem? In respect of Hungary the explanation is that in its constitution the Crown does not represent the King, but it is venerated as the symbol, the embodiment of the nation as a free independent state.

The idea of the Crown as a separate juristic personality resulted from historical development. Better understanding of the evolvement of this unique mystical and mythical concept through centuries necessitates a brief summary of the Crown's thousand years'

* Dr Iur Dr Pol (Budapest), LLB (NZ), Emeritus Professor of Law, University of Otago, legal consultant and writer. 
existence. As the principle evolved during times of peace, war and internal strife, jurists and historians pronounced similar, or even the same, opinions (which in this essay the reader may find repetitious) gradually refined to a doctrine where the Holy Crown as a supreme personality retained its paramountcy, its sovereignty even in a republican form of government. $^{1}$

\section{THE ORIGIN OF THE HUNGARIAN NATION}

Seven Ugaric tribes, ${ }^{2}$ the ancestors of the Hungarian nation, settled in the Carpathian basin and surrounding mountains at the end of the 9th century. The year given by historians is 896. Before taking possession of the land the chiefs of the tribes elected Álmos, leader of the largest, the Megyer tribe, ${ }^{3}$ as their paramount chief. Following pagan custom they cut their wrists, let some blood in a chalice, mixed them together, and all drank some. This blood covenant symbolised that as blood brothers they bound themselves to hold together against all enemies, but it created a loose association only. ${ }^{4}$

Álmos, like Moses in the Old Testament, died without seeing the "promised land" the Carpathian basin which they regarded as their heritage from their forefathers and kindred race, the Huns of Atilla. ${ }^{5}$ Árpád, son of Álmos, took over the leadership and led the conquering tribes. He proved himself not only a hero in war, but a wise and temperate ruler in peace. The chieftains of the tribes recognised him as supreme commandant and allowed him to consolidate his authority. ${ }^{6}$

1 Many sources referred to and some texts quoted are in Hungarian. Word for word translations would not always give the true sense intended (traddutori traditori), therefore the aim here is to convey the meaning in English by paraphrasing.

2 Nyék, Megyer, Kürtgyarmat, Tarjàn, Jenö Kér and Keszi; some small Kabar and Kazar units also joined. According to Byzantine chronicles ten tribes speaking a common language lived beside the Black Sea; they were called onogur, meaning ten tribes in Turkish. The Latin word Hungarus, English Hungarian, French Italian and German variations derive from that word; Konstantinos Porphyrogennetos, Konstantin VII, Byzantine emperor (905-959) wrote many historical and geographical works, about the Hungarian tribes before they settled in the Carpathian basin.

3 Myth, no historical proof. He regarded himself as a descendant of Atilla, King of the Huns. The word "magyar" as the Hungarians call themselves, is a variation of Megyer.

4 Anonymus, the nameless chronicler "Gesta Hungarorum" written at the end of 11th and beginning of 12th century; Kezai Gesta Hungarorum second half of the 13th century.

5 According to myth he was killed as a, sacrifice because in ancient belief a new land demands a new young leader to occupy and defend it.

6 Anonymus, above n 4; Konstantinos, above $\mathrm{n} 2$. 
When he died his successors unfortunately lacked his wisdom and strength. Chieftains turned against the weakened central authority, tribes fought between themselves for hegemony. Like the Vikings on their longboats who raided Britain plundering and killing, so the pagan tribesman riding on fast horses, caused havoc in the neighbouring German countries, Italy, Burgundy, Gaul and even Iberia. They never attacked the heavily armoured knights in frontal fight. After advancing, they quickly turned pretending flight, letting the enemy triumphantly chase them. One group rode right, other left forming a half circle around the pursuers. The main group suddenly turned back, and together with the left and right wing surprised the enemy with a shower of arrows. ${ }^{7}$ They could shoot with devastating aim while riding fast. Apparently the arrows were aimed at some unprotected part of the body, or the armour did not give good protection against the fast sharp arrows. When the surprised enemy became confused and disorganised, the raiders attacked with heavy maces and swords. ${ }^{8}$ These pagan tribesmen were the curse of the civilised Christian West.

Emperor Otto of the German-Roman Empire, however, soon learned the plunderers' tactics. He defeated the intruders in the field of Lech, near Augsburg, so heavily that only a few remained alive to take home the bad news. Further raids all ended with terrible loss of the attacking pagan bands. ${ }^{9}$

\section{ESTABLISHMENT OF THE CHRISTIAN KINGDOM}

The last ruling Prince, Géza, elected in 972, wisely realised that the irresponsible, illfated raids must be stopped, and unless peaceful relations were established with the Western Christian countries, his people would be destroyed, as had happened to many pagan nomadic tribes. He succeeded in making peace with Prince Henry of Bavaria, and to show his sincere good intentions asked for the assistance of the German church in introducing Christianity. ${ }^{10} \mathrm{He}$ himself received baptism also, but this was merely a political move, not a real conversion.

Vajk, his son, was baptised, received the name of the early Christian martyr, Stephanos - István in Hungarian. Invited monks educated him as a true Christian believer. By his

7 Anonymus, above n 4; Konstantinos; above n 2.

8 Bertényi, Diószegi, Horváth, Kalmár \& Szabó Királyok Kônyve (Book of Kings) (ed. Officina Nova, Gyula, 1995, 2nd ed) pp 10, 11; (hereinafter quoted as KK); Bodolai The Timeless Nation (Hungaria Publ, Sydney, 1978) pp 31-34.

9 KK Bertényi, above n 8; Bodolai, above n 8.

10 It is significant that he chose Western, not Eastern, Christianity. His wife, Sarolta (Charlotte), daughter of the second most powerful chieftain, Gyula, was already Christian. Because of contact with Christian countries both Western and Eastern Christianity was known and already accepted by many, especially by Gyula's tribe settled in Transylvania. Their pagan religion was not horrendous, they believed in one God and revered the spirits of ancestors. 
marriage to Gizella, a Bavarian Princess, a deeply religious woman, he strengthened the growing connections with the West.

Géza encouraged Christian missionary work, and re-established central control, though dissatisfied rebellious pagan relations constantly plotted against him. When he died in 997 István took his place, and continued the pacification and christianisation. Gizella inspired and assisted him in this task. ${ }^{11}$ In the year 1000, the first millennium, István sent legates to Rome, and asked the Pope to send a crown for his coronation as king. Pope Sylvester welcomed the legates, and donated a crown with his blessings for István's apostolic zeal in spreading the faith of Christ. ${ }^{12}$ The coronation took place in the recently built cathedral in Székesfehérvár. Two high-ranking priests performed the ceremony in accordance with the German ordo ${ }^{13}$ during a special high mass. They put the crown on his head, covered his back with the mantle, placed the mace and orb in his hand, and girdled his waist with the sword, while they held high the special apostolic cross. Following ancient tradition he was also anointed. ${ }^{14}$ A most important item followed. The priests and the whole congregation left the church. The king rode up a hill, drew the sword, made a cut towards the four points of the compass, and took the coronation oath solemnly swearing to defend the country against all enemies. ${ }^{15}$

Like his father, the first King had to defend himself and his missionary efforts against rebellious pagan chiefs, some of them his own relations who resented the "foreign" religion, wanted to restore the old order, and with their followers attacked the royal army. István, however, severely defeated and punished them. The leaders, Koppány and Ajtony suffered the cruel penalty: the head cut off, the body quartered and put on public show in different parts of the country as a deterrent. Medieval people did not see any contradiction between these horrendous punishments and true Christianity. ${ }^{16}$

11 Anonymus, above n 5; Konstantinos, above n 2; Maurer EA "The History of Hungary" in Magyar Szó 1993, pp 147, 148, 185; KK Bertényi, above n 9.

12 KK Bertényi, above n 9, pp 16, 19.

13 "Ordo" was a prescribed coronation ritual. At the coronation of Salamon, the English ordo was used (ruled 1063-1074); Eckhart, F Magyar Alkotmány Jogtörtenet (History of the Hungarian Constitution and Law) (Politzer, Budapest, 1946) p 90 and 88-93 in general.

14 KK Bertényi above n 9, 20: Maurer, above n 11, 23, Eckhart, above n 13, 95; Bodolai, above n 8, 35.

15 Eckhart, above n 13, 90-92; Kern, F Gottesgnadentum and Widerstandsrecht; Schramm, PE Geschiscte Des englischen Königtums in Lichte der Krönung Weimar 1947; Bartoniek E A Magyar király koronázások története ed Franklin (no year) (History of Coronation of Hungarian Kings); KK Bertényi above n 8, 20, 21; Bodolai op cit 35-38.

16 KK Bertényi above n 8, 16, 17; Bodolai above n 8, 35 . 
István intensified Géza's efforts, invited more German and Italian clergymen and monks, mainly Benedictines. With his support they founded monasteries, built churches, and taught the people, now living in permanent settlements, agriculture and viniculture. The pastoral, nomadic lifestyle, always seeking new pastures was abandoned, as it became impossible in the changed circumstances. ${ }^{17}$

Soon after his coronation the king issued a Code in 1001, and in 1008 a second one. The famous Institutiones Morum ${ }^{18}$ intended for his son, Prince Imre, followed in 1018. By these Codes István organised an independent Hungarian church, established ecclesiastical districts, and secured their financial needs. As apostolic king he had the right of appointing bishops. The bishop of Esztergom received the rank of archbishop with the approval of the Pope.

Parallel with ecclesiastical organisation the king also laid down the pattern of secular administration. On the Frankish model he divided the country into counties (comitia), appointed an Ispán as its chief administrative official and also commandant of the Royal castle's garrison. He ordered that any Ispán in the future could be appointed only by the king. The second in charge, the royal Judge, was entrusted with various administrative and judicial tasks, the most important being the collecting of taxes. ${ }^{19}$

The king himself travelled around the country with all his councillors, officials and servants. ${ }^{20}$ The chief office holder, the Palantinus, ${ }^{21}$ had after the king the widest administrative and judicial power. He acted in the name of the king as his deputy. All other court officials worked under him.

The establishment of the country as an organised Christian kingdom, laying down the foundations of a complex system of administration which basically remained during the following 1000 years, the transformation of a loose association of pagan nomadic tribes into a civilised Christian nation, an organised country equal with those in the West,

17 KK Bertényi above n 8, 18, 19; Bodolai above n 8, 35-38.

18 Moral admonitions on the pattern of Justinian's Institutes in 533; a kind of textbook on the proper conduct, duties and rights of a good Christian king; the text in Latin, no doubt, was drafted by learned monks on the King's instructions.

19 KK Bertényi above n 8, 18, 19; Bodolai above n 8, 35-38; no author named Magyar Alkotmánytörténet (History of the Hungarian Constitution, publ Osiris) contains a detailed enumeration of the royal rights and privileges.

20 KK Bertényi abover n 8, 18-22.

21 Nádor in Hungarian, the office of the Palatinus remained an important institution until the 19th century. 
without doubt, can be attributed to the first king, István. ${ }^{22}$ For his missionary work the church canonised him in 1083 . His right hand was found whole and intact, not putrefied. The church declared it as God's miracle. ${ }^{23}$ Posterity remembers and reveres Szent István as the greatest king, the father of the nation, founder of the country.

\section{THE SIGNIFICANCE OF THE CORONATION}

From ancient times the leader of an ethnic or religious community was inaugurated by a specific ceremony. The pagan Hungarian tribes lifted up the person elected as paramount chief on a shield, thereby elevating him over all others. ${ }^{24}$ The Jewish kings, ${ }^{25}$ according to the Old Testament, were anointed by the chief priest. The Celtic Britons in the 6th century $\mathrm{AD}$, and the Western Goths in the 7th century, performed a similar ritual at the investiture of their kings. ${ }^{26}$

Gradually other procedures evolved: presenting the new king precious jewels, placing a golden helmet on his head, or a golden tiara ornamented with gems. The tiara became a crown on the king's head as a clear signal of his high status, the most high over his people. ${ }^{27}$ With the general acceptance of Christianity and the great spiritual power of the church the coronation of the king gained a religious character performed during the high mass in a church by high-ranking priests, bishops, archbishops. The ceremony emphasised that God granted the power of the King, he was King by the Grace of God, and by the solemn ritual became sacrosanct, a divine person in human form, not an ordinary man. ${ }^{28}$ The crowning conveyed the clear message to the people that disobeying, rebelling against, the King would not be an ordinary secular crime punished by the King's judges, but a grave sin against God, a blasphemy for which the sinner would be excommunicated and suffer external damnation in hell. ${ }^{29}$ The Holy Crown gained such an aura that a coronation with any other crown

22 KK Bertényi above n 8, 18 ff; Bodolai above n 8, 35-38.

23 KK Bertényi above n 8, 19; at the same occasion, his son Prince Imre and Bishop Gellért (Gerard) also were canonised.

24 Konstantin, above n 2.

25 I Kings ch 19, verses 15, 16; II Kings ch 9, vs 1-13; also in other places; Metzger \& Coogan The Oxford Companion to the Bible (Oxford U P, 1993) 30, 31.

26 Eckhart, above n 13, 88, 89.

27 Eckhart, above n 13, 90-93.

28 Later the Nádor and the Chief Justice of the country performed, or participated in the coronation ceremony when the ecclesiastical character of it became a public law signfiicance; Eckhart, above n 13, 90.

29 Osiris above n 19, 2; Kardos J A Szent Korona Tan Története (History of the Holy Crown Concept), 1919-1944, (Akadémia publ, Budapest, 1985) 11. 
was not accepted by the estates as valid. Queen Elizabeth, widow of King Albert, arranged the stealing of the crown, and it was in the possession of Emperor Frederick III. ${ }^{30}$ When after long civil strife the estates elected Matthias as king in 1458, it took him six years' protracted negotiations to get the crown back. In a letter inviting the city of Pozsony to his coronation Matthias emphasised that he aspired to "wearing the country's crown, the basis of royal dignity, and strength for the sake of public good and his own honour". 31

The divine right of the King, the principle that the King is above the law, "the king can do not wrong" remained valid in England for a long time, and similarly in many European states. As the King was the head of the state, the peak of all legal structure, he could not be impleaded in his own courts. This doctrine prevailed in England until the Crown Proceedings Act 1947.32

Even well after the feudal era many monarchs retained their absolute power. The unrestrained conduct of King Henry VIII, his forcible divorces and death penalty suffered by his former wives, certainly would and could not be approved by later monarchs. No King nowadays could do such blatant atrocities, but Henry's word was law. His daughter, Elizabeth I, though she was held in high esteem by the population and posterity, still ruled absolutely. ${ }^{33}$ Even as late as the end of the 17 th and beginning of the 18th century, the king of France, Louis XIV, could declare "L'état c'est moi".

In England during the Stuart kings the Parliament gained supremacy: After the beheading of Charles I and the Cromwell era when the monarchy was restored with Charles II, the present constitution system commenced to evolve. In France the revolution in 1789 finished, somewhat abruptly, the absolute power of the kings.

It may be noted that in Japan the status of the Emperor as a divine person came to an end only with the American occupation.

\section{$V$ THE CROWN AND THE CORONATION JEWELS}

At this juncture it seems necessary to say a few words about the physical aspects of the crown and the other jewels before discussing their legal and constitutional significance.

30 In 1440; KK Bertényi above n 8, 78-81; Eckhart above n 13, 92; Kardos above n 29, 12; see below Part X "Loss, Recovery and Guarding of the Crown".

31 Kardos above n 29, 15, 16; Teleki J Hunyadiak kora (The age of the Hunyadis) X1 p 81; see below nn 49 and 50.

32 Walker, DM The Oxford Companion to Law (Clarendon, Oxford, 1980) 702.

33 Brown, I Shakespeare in his Time (Thomas \& Sons, Edinburgh, 1960) the author depicts the time of insecurity when the Queen could elevate, reduce, or order the execution of any person according to her whim. 
They are all beautiful products of the medieval goldsmiths art. Detailed description of these golden jewels with precious stones and pictures is for goldsmiths, experts in ancient ornaments.

The crown in Hungary, traditionally called Szent István's Crown, in fact is not the one he was crowned with. The closed crown covering the head sent by the Pope was used at the coronation of István. Michael Dukas, Byzantine Emperor donated around 1070 an open crown. The two crowns soldered together created the crown as it appears now, and which came to be called Szent István's Crown, the Holy Crown. ${ }^{34}$ Historical research has proved that this cannot be true, as the little tablets on it showing Michael Dukas and Géza I, the Hungarian king who ruled at the time of the donation could not have been depicted about 70 years earlier. This belief, mythical, however became accepted as fact. ${ }^{35}$

Secondary to the crown other important coronation insignia are: the mace, the orb and the sword. Queen Gizella herself embroidered the mantle according to mythical belief, but in fact it had been a mass robe for priests, and only later was altered for the king's coronation robe. ${ }^{36}$

The golden apostolic cross played also a most fundamental role in the coronation ceremony. It was believed that the Pope sent it together with the crown as a reward for István's apostolic zeal. The cross is shown in the coat of arms with two horizontal branches. Until the 20th century it was also generally believed that the Pope donated such a cross as one of the coronation jewels with a document, a Papal Bulla which said that "we allow, want and ask for now and for the future after the king's coronation crucem insuper ante regi ferendam velut in signum apostolatus misit". ${ }^{37}$

Ivánfi, in the 19th Century had no doubt of the authenticity of the Papal Bull. He quotes earlier sources in support, but even the oldest of them was written centuries after the alleged event. ${ }^{38}$ In Eckhart's opinion, however, the Papal Bull is a purposeful forgery from a much later time. ${ }^{39}$ Donászy expressed the view that what the Pope gave was an ordinary

34 KK Bertényi above n 8, 20; Bodolai above n 8, 35, 37; Eckhart above n 13, 94; Tomcsányi M Magyar Közjog, Alkotmányjog (Hungarian Public Law, Constitutional Law) (Budapest, 1926) 122123.

KK Bertényi above n 8, 21.

36 Eckhart above n 13, 94; KK Bertényi above n 8, 20.

37 Ivánfi, E Magyarország cimerei (Hungary's Coats of Arm) ed Lauffer 1869, republished in facsimile with new essays bringing it up to date, Maecenas, Budapest, 1989, 17; Palma Heraldica $\mathrm{RH}$ spec 18.

38 Ivánfi above $\mathrm{n} 37,16$ ff.

39 Eckhart above n 13, 298. 
Latin cross. According to him at the time of the first millennium an apostolic cross had only one horizontal bar, the two-pronged cross was invented in, and originated from, Byzantium. The Western church adopted it only later. ${ }^{40}$

Another ancient national symbol is the "Turul", a kind of mythical bird. Historians think it may be an eagle, but definitely not a vulture. In Kállay's opinion it is most probably a hunting falcon. It was used in pagan times; it remained, however, and was regarded as an emblem coexisting with the Christian ones. ${ }^{41}$

\section{SEPARATION OF CROWN FROM THE KING}

Szent István ruled with absolute power and he used it wisely for the benefit of the nation. His councillors gave him advice, but the King made the final decision alone. István's only son, Prince Imre, ${ }^{42}$ died young before his father. After the King's death in 1038, as there was no direct successor, several relations contested and fought for the Crown. When on the throne, they ruled or tried to rule with absolute power. As their position was insecure their councillors' advice mostly became the King's decision. With the help of a group of powerful nobles, owners of big estates, a pretender could depose, and actually deposed a ruling king, took his place, and suffered the same fate a few years later. ${ }^{43}$

The councillors, chief nobles and high priests evolved into the Royal Council. During the time of István's successors they were the actual decision makers.

Originally the King owned all land in the country as the superior landlord and overlord. He had the right of granting land to inferior lords as fiefs who in turn gave land to their supporters as subfeudation. The fiefs all had certain duties to their higher lord. At the bottom of this system were the serfs who had no rights or hardly any rights. ${ }^{44}$

In order to gain the loyalty and support of the influential chief nobles, the members of the Council, the weak Kings donated large pieces of land to them. Instead of supporting the

40 Donászy, F Nemzeti Jelvényeink Története (History of our National Emblems); Székey G A Kettés Kereszt Utja Bizeancból Latin Europába (The Travel of the Two-pronged Cross from Byzentium to Latin Europe), in Ivánfi, Appendix, 107.

41 Ivánfi above n 37, 13, 12; Kállay I Nemzeti Jelvényeink Idöszerüsége (Timeliness of our National Emblems), Ivánfi, appendix 152; Kézai S Chronicles.

42 His mother was Queen Gizella; the name Imre is the Hungarian form of Emericus, Heinrich in German, Henry in English, Enrico in Italian, Amerigo in Spanish.

43 Peter Orseolo, István's nephew ruled from 1038 to 1041; in that year he was deposed and Aba Samuel, another nephew took his place. Emperor Henry in 1044 forcibly reinstated Peter. Pagans rebelled, captured and blinded him. He soon died; KK Bertényi above n 8, 22, 23; Kardos above $\mathrm{n} 29,12$.

44 Walker above n 37, 466-467; as to serfs see below $n 54$. 
King, however, the big landowners became aggressive, disregarded, disobeyed and even forcibly resisted the king. They assumed complete domination and quasi independent rule over their territories, and behaved like sovereign kings or oligarchs. ${ }^{45}$

The common nobles, the servientes royal, were afraid of the increased power of the Royal Council, which was in fact the powerful oligarch families. Finally, in 1222 they forced King András II, one of the weakest kings, to issue the Bulla Aurea, the Golden Bull. The magnates supported them against the King. ${ }^{46}$ In this document the King promised to secure personal freedom and exemption from taxation to the servientes royal, the common nobles, but made them liable for military service in war. The Bulla also contained the clause of ius resistendi, the right to resist any illegal action of the King. The second Golden Bull in 1231 amending the first one, however, repealed the right to resist, and inserted instead the penalty of excommunication by the Archbishop of Esztergom. The King broke all his promises and therefore in 1232 after the Archbishop pronounced interdict he was forced to obey. The Bulla also promised to remedy all grievances of the church. ${ }^{47}$

Although the second Bulla did not contain the clause of ius resistendi, it still may be regarded as the earliest medieval document in shaping the Hungarian constitution.

The predecessors of King Béla IV (1235-1270) gave away so much land to their supporters that when he came to the throne the royal domain had shrunk to a relatively small area. King Béla claimed back and repossessed much of the carelessly donated lands referring not to his right as King but the right of the Crown, as distinct from the person of the King. ${ }^{48}$ Kardos, a constitutional historian commented:

The Crown commenced to develop into a concept separated from the king's person, with independent rights and liberties which owns the inalienable royal estates ... [The] donating away of royal possessions, the weakening of the royal power, at the beginning of feudal anarchy converted the concept of the Crown into the ideological support of state power.

The barons and the chief priest asserted that not the King but they owned the Crown. With the rise of the common nobility organised into an estate of the country they claimed also participation in state power, and consequently part ownership of the Crown. ${ }^{49}$ This

45 KK Bertényi above n 8, 46, 47, 62, 63.

46 The Magna Carta of 1215 in England issued by king John granted rights and liberties to the church and to all freemen; was the Golden Bull influenced by it, or are the dates mere coincidence?

47 KK Bertényi above n 8, 46, 47; Bodolai above n 8, 40, 41.

48 Osiris above n 19, 3; Kardos above n 29, 12.

49 Kardos above n 29, 12, 14, 17; see 30, 41; Osiris above n 19, 3, 4. 
idea gave rise to the further consequential one that the power was possessed by the crown. Thus, coronation with any other crown did not give the person pretending to be king the status of a real king.

The Royal Council by the 15th century developed into the Upper House of the National Assembly, and the common nobles, the servientes royal, formed the Lower House. Only the nobles were regarded as members of the nation. Free royal cities, the different craft guilds also gained recognition at a later time. The estates announced that the coronation of a king depended on the country's population - the efficacy of the Crown came from their approbation. ${ }^{50}$

The private law dominion of the king thus gave place to a public law position. The Crown became a legal person, a public law entity. Instead of representing the monarch's absolute, divine rights, it acquired a role of restricting royal power and giving to the estates, the barons and the common nobles, a substantial share in state power, attributed from then on to the Crown, not to the person of the ruling king. This new constitutional idea effectively changed into the means of the estate's claim for more involvement in governing the state, ${ }^{51}$ and the Crown, now opposite to the king, altered its character into an institution supporting the estates' power and restricting the king. ${ }^{52}$

By the 15th century Szent István's Crown, already called the Holy Crown, was clearly recognised as a separate entity, distinct from the king, a legal person in its own right. At the beginning of the 16th century Werböczy in his Tripartitum pronounced it as a settled principle that the king and the collectivity of the nation together exercised the state's authority; they possessed in mutual dependence the fullness of power. The fountain head of the royal power was the entirety of the nobles; all power was granted to the king by the coronation. The Crown is the embodiment of the public power. ${ }^{53}$

The nation in Werböczy's view consisted of the nobles, the magnates and the common nobles, because though the barons owned more land, the common nobles had the same rights: una eadem nobilitas, they had the same nobility. It is noteworthy that while Werböczy declared the same status for common nobles, he absolutely disregarded the poor masses, the serfs, who were not recognised as parts of the nation until 1848. Werböczy argued that the serfs committed crimes, were sinful against the interest of the community, they did not

50 See above $\mathrm{nn} 30,31$.

51 Kardos above n 29, 12-15.

52 Osiris above $\mathrm{n} 19,3$.

53 Bertényi A Magyar Államcimer Fogalmának Kialakulása (The Developing of Hungarian State Emblem concept) in Ivánfi, appendix 129. 
deserve any rights, and could not be accepted as part of the nation. ${ }^{54}$ The Golden Bull served mostly the interests of the common nobles.

\section{THE HABSBURG KINGS AND THE HOLY CROWN}

After the victory of the huge Turkish army at Mohács in 1526 where King Lajos II died, a period of chaotic conditions started. The nobles disagreed. One faction elected János Szapolyay, a Hungarian magnate, as king the other elected Ferdinand Habsburg, Archprince of Austria, brother of Lajos' widow. The two factions fought until Charles V, the German Emperor arranged peace. By this treaty both recognised the other as king in the territories actually held by them. János also agreed that after his death Ferdinand should be the sole ruler followed by his successors.

This treaty deprived the nation, the nobles, from the right of electing a king while any Habsburg descendant could claim the throne..$^{55}$

Despite this solemn treaty King János named his son János Zsigmond as his successor. As a result of many internal and external armed conflicts János' position weakened, and he placed himself under the protection of the Sultan. Later he abdicated as King of Hungary, and took the title, Prince of Transylvania. From that time Transylvania (Erdély) was a separate country, a principality, governed by a ruling Prince until 1711 . By the end of the 17th century the Turks were driven out of Hungary and the imperial army occupied Transylvania. The Habsburg dynasty then commenced ruling over the whole country. ${ }^{56}$

The Habsburg kings were also emperors of the German Empire which by the 17th and 18 th centuries was merely a loose confederation of semi-independent states. Prussia, Bavaria and Saxony had their own king, army and foreign policy. The numerous principalities and free cities similarly acted as independently as they wanted - or could. Prussia and the north in general accepted Luther's teachings, while the south, among them Bavaria and Austria, remained staunchly Catholic. The emperor-kings intended to make

54 Werböczy I Tripartitum 1514, codification of customary law in three parts. A committee of the National Assembly recommended enactment of it, but because of the Turkish invasion and the following troubles it never was done. Still it was published, and the collection of statutes included it in 1628, was officially used from 1696. In 1514, before the publication of Werböczy's work there was a rebellion of serfs harming and killing many nobles. The rebellion was cruelly suppressed, the leaders executed by sword, or breaking on the wheel. Werböczy himself was a common noble. Kardos above $n 29,16,17$.

55 KK Bertényi above n 8, 86-89; Bodolai above n 8, 67-70, 93-98; Kardos above n 29, 13-16.

56 KK Kalmár above n 8, 94-95; Szabó above n 8, 124, 125, 128-163; Bodolai above n 8, 97-100. 
their multilingual possessions Catholic and German. In their absolutistic centralisation efforts Hungary was merely one of their provinces. ${ }^{57}$

In the 16th century many Hungarians became Protestant, accepting mainly Calvinism. In the 17th century, however, a Jesuit priest, Peter Pázmány conducted a vigorous reconversion, counter-reformation. To allay the Hungarians' fears of German Catholic domination he emphasised that Catholicism did not contradict being independent. He was fairly successful, about two-thirds of the population today is Catholic, but one-third belongs to one of the protestant churches. In Transylvania which became a separate country after János Zsigmond, the ruling Prince secularised Catholic church estates, prohibited Jesuits, and encouraged religious equality. ${ }^{58}$

For the Habsburgs the Holy Crown was only one of their crowns, not the most important. They endeavoured to manipulate the Crown as the representation of the king alone, and denied the nobles' rights as members of the Holy Crown. Conversely, they claimed territories under Turkish or Transylvanian rule referring to the right of the Crown, arguing that those territories belonged to the jurisdiction of the Crown. ${ }^{59}$

The Hungarian nobles supported the king in re-occupying lands from the weakening Ottomans, but at the same time resisted any attempt against the constitution.

As the kings disregarded protests from estates, and insisted that the crown belonged to them as their property, the crown several times was taken out of Hungary. Joseph II, son of Maria Theresa, ordered it to be brought to Vienna, but he refused coronation, as the oath included the solemn promise of preserving Hungary's independence. ${ }^{60} \mathrm{He}$ ruled with absolute power, and intended introducing reforms. His centralising and modernising ambitions, however, completely disregarded the Hungarian constitution. Among other things he ordered that the language of administration should be German. ${ }^{61}$

57 Bodolai above n 8, 103, 119-126; KK Diószegi above n 8, 165, 166, 170-175; Kardos above n 29, 17.

58 Bodolai above n 8, 102-104; KK Diószegi above n 8, 164-199.

59 Kardos above n 29, 17, 18; Bodolai above n 8, 126; Ivánfi above n 31, 95; KK Kalmár above n 8, 114-115; Szabó above n 8, 130.

60 He was referred to as "the hatted king"; KK Diószegi above n 8, 178-179, 180-181; Bodolai above n $8,126$.

61 The language of administration and the courts until 1848 in Hungary was Latin. The story says that when a German order or letter arrived, it was catalogued as "Germanica scripta, non leguntur", and they took no action. As to the wanderings of the Crown below see Part X "Loss, Recovery and Guarding of the Crown". 
In the Habsburg centralisation efforts the using of the Crown concept received a manipulative role, they wished to appropriate it from the estates ideology and do the opposite to it. $^{62}$

These efforts gravely offended the nation. The common nobles organised in the counties resisted, and asserted that the Crown meant the nation, not the king alone, not royal power; therefore the king's action were not of, but against the Crown.

On his deathbed, Joseph, frustrated in his reforming zeal, withdrew all his "illegal" orders. While he was dying the crown returned in a triumphal procession to Buda. On its way the people greeted it everywhere with joy and jubilation. Not only the conservative nobles but many persons influenced by the spirit of the 18th century enlightenment, and even sympathetic to the ideas of the French revolution honoured, and paid homage to the Crown. ${ }^{63}$ It illustrates the general respect and love people feel and always felt. The Jozefinista Miklós Révai, a Professor in Györ, who accepted the ideas of enlightenment, wrote a serenade to the Crown when it stopped there in the journey:

Our sun's dawning, our country's renewal,

Our sky's lightening, our laws' force and strength

Our freedom's wholeness, our nation's life,

Our desire's aim, our wound's healing,

Our complaints ceasing, our joy's beginning.

Batsányi, a poet who was attracted to the ideas of the then recent French revolution (where the King and Queen were sent to the Guillotine) wrote: ${ }^{64}$

The country's glorious Crown returned with full force of language, law and freedom.

\section{THE HOLY CROWN CONCEPT UNTIL THE COLLAPSE OF THE HABSBURG EMPIRE}

At the end of the 18th and during the first part of the 19th century, the reform era, the definition of "nation" underwent a radical broadening. The machinery of the state functioned after the Napoleonic wars on the antiquated medieval style. The National Assembly consisted of the Barons and Catholic prelates in the Upper House. In the Lower House the common nobles were represented by two delegates sent by each county, and

62 Kardos above n 31, 17; Osiris 3 above $n$ 13, 3.

63 Kardos above n 31, 18; KK Diószegi above n 8, 178, 181.

64 Nemeskürty, I Bucsupillantás (Farewell Glance) (Szabadtér Publ, Budapest, 1995) pp 309-310; in translation the rhythm of the Hungarian text is lost. 
deputies of the free cities. The common people, the serfs had nobody to appear for them, they had no rights because they were not part of the nation in Werböczt's definition. ${ }^{65}$

The common nobles, who earlier mainly complained about grievances of the ancient constitution, now influenced by the ideas of the enlightenment and the French revolution demanded reforms and successfully convinced the majority of both houses of the need to modernise the country. ${ }^{66}$

Most important, as Kölcsey ${ }^{67}$ noted, was the abolishing of serfdom, giving ownership of land to the free peasants, making them part of the nation, granting them all civil rights, and in general transforming the antiquated administration according to western, mainly English pattern. Széchenyi, an aristocrat by birth, a great admirer of the English system, said that Hungary could not be a happy developed country "until we elevate all the people in the ranks of the nation". 68 Kossuth while defending the ancient constitution, considered that broadening the Holy Crown concept meant not only granting rights to the excluded millions but it would help defend the constitution, strengthen it and striving for independence. ${ }^{69}$

A modern historian remarked: ${ }^{70}$

When the concept of the nation as being only the nobles with the reception of the people broadened into a civic one, in the same way the feudal idea of the Crown changed into a civil notion, built in the emerging civilian, egalitarian political thinking. This means an ideological transubstantiation showing continuity in form but in essence transfused with new ideas.

65 See above $n 54$.

66 Bodolai above n 8, 145-148; KK Diószegi above n 8, 184; Kardos above n 29, 18-20.

67 A classical poet, common noble, who wrote the words of the Hungarian national anthem; Kardos above $n$ 29, 18-20.

68 Count, István, author of several books urging economic and social changes. The first permanent bridge on the Danube betwen Buda and Pest was built at his instigation by Adam Clerk, English engineer; and there were many other projects; see Kardos above n 29, 20-12; Bodolai above n 8 , 146.

69 Lajos Kossuth was the leader of the independence movement; Kardos above n 29, 21; Bodolai above $n$ 8, 146-148.

70 Arató E A Nemzet, a Haza fogalmának alakulása Magyaror szágon a felvilágosodástòl a kiegyesésig (Evolvement of the nation, fatherland concept in Hungary from the enlightenment to the compromise), ELTE yearbook, 1966, p 20; Kardos above n 29, 26. 
By 1848 , the year of the revolutions in Europe, the reform and independence ideas gave vent in the uprising on 15 March led by the young Petöfi and Jókai ${ }^{71}$ resulted first in a lenient attitude in Vienna. The King-Emperor Ferdinand V, agreed to the formation of a responsible government, abolition of serfdom, parliamentary elections by popular vote, freedom of religion and press. Although about one-third of the population remained Protestant after the counter-reformation, the Reformed (Calvinist) and Lutheran churches were not recognised, merely tolerated. They had no representation in the National Assembly. A national Hungarian defence force, the Honvéd army, distinct from the imperial forces, also was established..$^{72}$

Viennese policy, however, hardened. The new Chancellor, Kolowrat, hated the Hungarians. On the demand of the Imperial Council, the benign but imbecile Emperor-King, Ferdinand, abdicated, and his young nephew, the 18 year old Francis Joseph took the throne. The Council repudiated the constitution approved by the former king, and ordered the imperial army to crush the Hungarian "revolution". The newly formed Hungarian Honvéd Army, however, proved successful, and the Emperor-King asked the Russian Tsar for help. A Russian Army of 200,000 would now defeat the already exhausted Honvéd troops.

Cruel revenge followed. Thirteen generals received death sentences and were immediately executed, officers suffered long prison sentences, others were pressed in to service as common soldiers in the Austrian Army. ${ }^{73}$ Hungary became again an oppressed province, all reforms abolished, and constitution disregarded. Vienna ordered administration with German as the official language and met a passive resistance. Not understanding anything, non-obedience, frustrating the poor Austrian clerks sent to administer the country, created near chaos. ${ }^{74}$ This oppression lasted for nearly twenty years, until 1867, when a wise old Hungarian, Deák, arranged a compromise settlement. The King then recognised the 1848 constitution. ${ }^{75}$

External political events, nevertheless, greatly influenced the conduct of the Vienna Imperial Council. Prussia, the leading German state, defeated Austria in an armed conflict, which as a result lost all influence among the German states. At the same time Austria also

71 Petöfi S, poet, died (or disappeared) in the freedom war, at the age of 26: Jókai, novelist, died in 1902; they were supported by young students and many older persons; Bodolai above n 8, 148151.

72 Bodolai, above n 71; KK Diószegi above n 8, 192, 193.

73 Bodolai, above n 8, 151-154; KK Diószegi above n 8, 188-197.

74 See note 8 , above; Bodolai above $\mathrm{n} 8,171$.

75 Deák F, was a member of the first cabinet in 1848; reconciliation; KK Diószegi above n 8, 196-199. 
lost all possessions in northern Italy. Therefore, the support of the Hungarians was a necessity to save as much as possible. ${ }^{76}$

The monarch now recognised Hungary as a separate kingdom. He was crowned with the traditional ceremony in which he had to take the oath to preserve the nation's independence. By this act the Austrian-Hungarian monarchy came to existence with a personal union, but with two separate Parliaments and Governments. External affairs and defence, nevertheless, remained common. ${ }^{77}$

During the era of dualism the concept of the Holy Crown again came to the forefront of national thinking. According to Timon the royal power definitely gained a public law basis, and changed into public power restricted by the constitution. He said: ${ }^{78}$

Legislation and the power of the king is gradually losing its royal character, members of the Holy Crown participate to a greater extent and more independently in its exercise.

Another noteworthy observation he made was: ${ }^{79}$

The independent life of the Hungarian nation, its international independence, stands or falls with the Holy Crown.

Ferdinándy in 1917 expressed the view that the Holy Crown concept had to be preserved in order to maintain personal union with Austria. If Hungary did not want to melt into Austria, then the Holy Crown fiction must be maintained. The Hungarian Holy Crown which gave the king the right to reign and exercise royal powers is "obviously and perceptibly quite separate from the imperial crown". 80

\section{KINGDOM WITHOUT A KING - THE IMPORTANCE OF THE HOLY CROWN}

With the loss of the First World War the Austro-Hungarian monarchy came to an end. The victorious states forced the last King, Károly IV, to abdicate, and interned him, together

76 Defeat by the Prussians at Konigratz 1866; lost battle at Solferino; Bodolai above n 8, 171, 172; KK Diószegi, above n 75 .

77 KK Diószegi, above n 8, 198, 201.

78 Timon A Magyar Alkotmány és Jogtörténet (History of the Hungarian Constitution and Law) (Budapest, 1903) p 5; Kardos above n 31, 29.

79 Timon above n 78, 14; Kardos above n 31, 30.

80 Ferdinándy G Gróf Széchenyi István mint közjogäsz (Count István Széchenyi as public lawyer), (Budapesti Szemle, 1919) 151; Kardos above n 31, 33. 
with his family. Hungary lost about three-quarters of its former territory by the Treaty of Trianon which also forbade the return of Károly or any other Habsburg king. ${ }^{81}$

The diminished country, nevertheless, remained a monarchy, but without a king. The Parliament elected a Regent, as the interim head of state, until a king could take over. The Regent, Miklós Horthy had been an admiral in the former Austro-Hungarian navy. ${ }^{82} \mathrm{~A}$ kingdom without a king, and an admiral as head of a landlocked country. Foreign observers regarded this as an anomaly. This decision of the Parliament did not concern a person but the form of state. In a Hungarian monarchical form of state not the person of the king, and definitely not the Regent, means its most essential incarnation, but the Holy Crown. Hungary's actual ruler is the Holy Crown which unifies the population of the country into a nation. ${ }^{83}$

In this constitutional arrangement the role of the Holy Crown gained an extraordinary importance. Professor Tnmcsányi, a prominent constitutional jurist stated: ${ }^{84}$

The Holy Crown means the Hungarian state, the Holy Crown is the subject of state power, every power of the state is possessed by the Holy Crown. It unifies in itself the chief ingredients of the state: the nation and the king who are elements of the Holy Crown. The two sides together constitute the entire body of the Holy Crown. Full exercise of the highest state power can be performed only by the complete body of the Holy Crown, that is the king and the nation acting together.

The concept of the Holy Crown expresses the constitutional principle that the Hungarian state is comprised of the king and the members of the nation. The Crown, however, has a distinct, separate existence. In other words, the state power belongs neither to the king, nor to the members of the nation, but to the entire state as such made up by them that is the Holy Crown. The Crown is the highest, the superlative person, the king and the nation as members merely function as organs of the Crown. They do not, and cannot, exercise any power in their own right, but merely as elements of the Crown. ${ }^{85}$

81 Bodolai above n 8, 222; Memeskürty above n 64, 305; Osiris above n 13, 11 seq: Kardos above n 31, 45-59.

82 Bodolai above n 8, 224, 225; KK Diószegi, above n 8, 213-225; Osiris, above n 13, 11, 12; Kardos above $\mathrm{n} 31,45 \mathrm{ff}$.

83 Nemeskürty above n 64, 305.

84 Tomcsányi M, above n 34, p 120 ff; Kardos, above n 31, 17; Osiris, above n 8, 3, 4; Nemeskürty, above $\mathrm{n} 64,304$.

85 Tomcsányi, above n 34, 121. 


\section{Tomcsányi briefly summarised: 86}

The Hungarian state power is a public law power exercised by the king and the nation in right of the Holy Crown.

The Crown, as stated by several jurists, is a person on its own right, a juristic person, a personne morale, a fictitious person. As it embodies the state, nevertheless, in fact it is a very real person, a living person, the personification of the state's most superior power and authority. It may seem a paradox to assert that this is a fiction and at the same time call it a very real living person. This is the mystique of the Holy Crown. ${ }^{87}$

This concept gained particular relevance during the period 1920-1945. The Regent as head of state did not have the same constitutional authority as a king. The army, however, still was called the Royal Defence Force, the courts functioned as royal courts, the ministers, the civil service, the post office, the state railways all had the word "royal" in their designations, but nothing could be announced, stated, or done "In the name of His Majesty the King", as there was no such person. It was not considered an appropriate way of referring to the Regent, as he filled an interim position only, and he himself did not want to overreach his status.

Whenever the highest authority had to be invoked, the Holy Crown was recognised as the only one. Thus, the courts delivered judgments "In the name of the Hungarian Holy Crown". 88

This "temporary" situation in fact lasted until 1944. German interference was a virtual takeover. The short-lived but disastrous Nazi regime was followed by a long Soviet occupation which culminated in the communist rule by Moscow puppets. ${ }^{89}$ All traditions and history were turned topsy-turvy. What was crime earlier became a praiseworthy act, and honest actions became crime. The crown itself at that time, was in American hands. ${ }^{90}$ Nobody knows whether fanatic communists would have preserved or broken it up to sell the precious stones and gold. This new dark age lasted for more than forty years.

In 1944 the Nazi Germans forcibly removed and interned the Regent. The invading Americans kept him in custody for a while, then allowed him to live in Portugal, where he died and was buried in the English military cemetery. It is noteworthy that while Tito

86 Tomcsányi, above n 34, 120.

87 Eckhart, above n 13, 92-144 ff; KK Kalmár above n 8, 90, 91.

88 Bodolai, above n 8, 226-228; KK Dioszegi, above n 8, 213-215; Kardos, above n 29, 51.

89 Bodolai, above n 8, 254-256.

90 KK Diószegi, above n 8, 215, see next Part. 
demanded that Horthy be handed over to him as a war criminal, the American and English authorities freed him and even gave him the honour of being buried among the English dead. 91

\section{RECOVERY AND GUARDING OF THE CROWN}

As a result of internal conflicts or enemy actions during its thousand years of existence the crown was several times unlawfully taken, stolen or, to prevent such loss, hidden. Only a few, the latest incidents are mentioned here.

After the tragic end of the 1848-1849 freedom war the crown was buried near Orsova, at the place where the Danube breaks through the Carpathian mountains. It was recovered four years later. At that time the cross on the top already had a crooked leaning, not an upright position. Other damages, loss of a small piece of gold and one sapphire, however, were carefully repaired.

When the Soviet army advanced to Hungary, the Crown had to be saved again. It was taken together with the other coronation paraphernalia and the Holy Right Hand to Germany where the occupying US army seized it, and held it as war booty. It was, nevertheless, some consolation that it did not fall in Communist hands. During the Soviet occupation after rigged elections the Communist Party, led by expatriates returned from Moscow, assumed sole power forming a puppet satellite government under the protection of the "liberators" and taking their orders from the Kremlin.

Relations between the former allies quickly deteriorated into a cold war. President Carter, hoping to improve relations, nevertheless, decided to return the crown to Hungary, notwithstanding that the Communists still had a firm grip on the country. Many Hungarians in the US and all over the world protested against this decision - even a number of American individuals, fifty Democrat members of the US House and the strong trade union confederation, the AFL-CIO. All these protestations, however, did not avail. On 5 and 6 January 1978 the Americans solemnly handed over the crown with the other articles to a "committee of Hungarian people", who were in fact specially chosen faithful members of the Party. Hundreds of police made sure that nobody else could go near the airport when the crown arrived. ${ }^{92}$

The communist government condemned monarchy as exploitation of the workers, and the crown as repugnant to Marxism. Fortunately it did not break up the coronation jewels as mere baubles, but recognised them as important historical relics and placed them in

91 Bagossy L Encyclopadia Hungarica Vol 1, Hungarian Ethnic Lexicon Foundation 1992, pp 755-756: see notes 92 and 93 .

92 Nemeskürty, above n 64,310 . 
safekeeping. In the National Museum in a bulletproof glass case the crown was exhibited, but a policeman always stood beside it. Whispering tongues spread the rumour that the objects in the glass case in fact were excellent copies.

Before the war two high-ranking persons, the Custodians of the Holy Crown, one Catholic and the other Protestant, were entrusted with the keys of the strongroom and the safes which held the crown and the other coronation paraphernalia. Only they had the privilege, acting together, of bringing out the royal jewels on the order of the Government. The actual guarding, day and night, was the duty of the Crown guards, a small detachment of specially selected officers and soldiers. They wore regular army uniforms with specific insignia. On ceremonial occasions, however, they had beautiful medieval-type garments and carried halberds.

The last commanding officer of the Crown guard troops, Colonel Pajtás, had the sad task of taking the coronation jewels out of the country. He believed in the mystique of the crown, never lost faith that the grace of God would rescue it from alien hands as the protector of the Hungarian nation, the symbol of its unity and inalienable rights. This faith, this love of the Crown, and a strong sense of belonging to it has always been shared by millions of ordinary people. ${ }^{93}$

\section{THE HOLY CROWN AS SYMBOL OF THE NEW REPUBLIC}

The year 1989 brought fundamental changes in all Soviet satellite states in Central and Eastern Europe. It was no surprise that the Communist Party, ${ }^{94}$ as a result of Gorbachev's policy and the falling apart of the Russian dominated Soviet empire, reappraised itself, and had no objection to a democratic change - democratic in the Western not the Marxist sense. The first multiparty elections reduced the communists to a minor opposition party. The Hungarian Democratic Forum which had 164 members formed the new government.

After this peaceful revolution - a radical transformation, nevertheless - the coat of arms remained unaltered. Legislative action was needed to abolish the Soviet style emblem and introduce a new, or rather revive, the ancient historical national insignia.

The Parliament debated the issue at length. There was no objection to reviving the historical coat of arms, the argument concerned only one point: whether or not it should be

93 Farkas Z Bujdosó Ereklyék 1945-1978 (Exiled relics), articles in Uj Magyarország magazin, 4, 11, 25 May, 1 and 8 June 1996.

94 The reformed Communist government years before the actual changes as soon as it was free from Moscow's interference, gradually moved toward capitalistic and free economy ideas. 
with or without the crown. Some excerpts from the members' speeches mirror the general feeling of the country. ${ }^{95}$

The Minister of Justice, Dr Balsai, proposed that the Republic's coat of arms should be the historical one with the Holy Crown on top of the shield. ${ }^{96}$

Köszeg $F$, though he objected to the inclusion of the crown still recognised its significance and said: 97

The Crown is a most important historical symbol, not only as one of the most ancient European crowns, but as an important symbol, an emblem which embodies a most momentous constitutional idea in state philosophy theories which I think should be preserved in some way.

Dr Zétényi, said:98

A democratic Hungarian state which after 50 years at the first time may call itself free following democratic elections cannot allow itself to be without a coat of arms, now already for two months. The coat of arms with the five pointed red star, I am glad to notice, this government is not willing to show.

Kállay, K commented:

When the coat of arms first was used with the Crown around 1385, there was no king but the country was a kingdom without a king. Therefore, the Crown does not directly depend on a king.

In respect of the popularly called Kossuth coat of arms, the one without the crown, he remarked that in fact it was not Kossuth who took it but it was the then young king, Francis Joseph who gave the order on 4 March $1849 .{ }^{99}$

The State Secretary in the Ministry of Foreign Affairs, Katona T commented: ${ }^{100}$

In the coat of arms of the Polish Republic the golden crown is placed on the head of the Jagellos' silver eagle, but with this the Polish republic did not cease to be a republic. We may

95 The records of Parliament, 11 June 1990-3 July 1990.

96 Parliamentary records, 3 July 990, p 1213.

97 Sz D Sz Alliance of Free Democrats; Parl Rec 3 July 1990, p 1215.

98 MDF, Hungarian Democratic Forum; Parl Rec 11 June 1990.

99 Parl Rec 11 June 1990: see The Holy Crown Concept until the Collapse of the Habsburg Empire, above Part VIII.

100 MDF, Parl Rec 3.7.90, p 1219. 
assert that the majority of the country's public opinion wishes the coat of arms with the Crown.

Teller, Gy observed: ${ }^{101}$

One of the meanings of the Crown is that it symbolises Hungarian statehood. When the state developed, it occurred in the concrete form of monarchy, and at that time the meaning of monarch and statehood was intertwined. When the monarchy ceased the meaning became abstract and then Crown and statehood became identical.

Csépe, B expressed his view: ${ }^{102}$

When we propose the coat of arms with the Crown, we do not identify ourselves with a monarch, but with Hungarian history. The Coat of Arms with the Crown represents most accurately the thousand years of Hungarian history.

He mentioned three dates when the crown was taken off the shield. In $1673 \mathrm{King}$ Leopold ordered removal of the crown image. Absolute rule followed, and in 1703 there was the freedom uprising with Rákóczi. In 1849 the absolute rule prohibited showing the crown. The freedom war was the answer. In 1946 the coat of arms was again deprived of the crown. After this came the oppression we all suffered under.

He concluded:

This change of regime must have a symbol connected with our thousand years' history which is more than sentiment. The man in the street feels like that ... I wish to emphasise that, in my conviction, the coat of arms with the Crown expresses most correctly the people's oneness with the thousand years' of Hungarian history.

Mr Csépe emphasised and concluded:

Certain negative meanings are not connected with the Crown: irredentism, fascism, nationalism and other similar ideas ... We attribute three meanings to the Crown. First, statehood, secondly continuity of statehood and thirdly belonging to Europe. These connotations cannot be left out of the state emblem. Therefore, I consider and propose that the coat of arms with the Crown should be the state emblem.

Following a debate whether or not the crown should be part of the coat of arms the Parliament voted for the inclusion of the crown with a majority of 258 votes against 28 noes

101 Sz D Sz, Parl Rec 3 July 1990, p 1220-1221.

102 KDNP, Christian Democratic People's Party, Parl Rec, 3 July 1990, p 1216. 
and 35 abstentions. As it was an amendment to the Constitution a two thirds majority was required. ${ }^{103}$

The statute as passed provides: ${ }^{104}$

The coat of arms of the Hungarian Republic is a pointed shield divided in the middle. First side, seven times cut red and silver stripes. The second, in a red field green triple mount with a golden crown projecting from its middle a silver two pronged cross. The Holy Crown rests on the shield.

\section{THE SUPREME PERSONALITY OF THE HOLY CROWN}

Personality attributed tc the Holy Crown is not a unique feature of the Hungarian constitution. Bestowing personality on inanimate things, physical objects, land or any kind of property has been a frequently applied fiction in civil law systems developed on principles of Roman law. In the French Civil Code, a fund to be used for a specified, a public, or a charitable purpose, a fondation, has a personality on its own. ${ }^{105}$ Similarly the Stiftung in German law, a fund for some philanthropic purpose, is not owned by anybody, it owns itself. The fund is a juristic person. ${ }^{106}$

Charitable funds in common law countries are vested in trustees, natural persons. They own it. This is, however, a mere fiction, they are duty bound to apply it strictly for the purposes as set out in the document creating the trust. In essence they have the same task as the persons, charged with the administration of the fondation or Stiftung. The juristic device of trust in common law, the fondation and Stiftung in civil law, are merely different fictions to achieve the same aim.

It must be emphasised that the Royal Crown has an important role also in the English and the New Zealand constitution. The word "Crown" means "Her Majesty the Queen", or the ruling monarch for the time being. The government and all state services function in the name, as servants or agents, for the Crown. The word "Crown" in common usage refers to the state, the state authorities. The fiction, nevertheless, is always upheld that the Queen does everything through and by her servants. The Crown and the ruling monarch are identified. Therefore if there is no ruling monarch the "crown" becomes merely a most valuable jewel without any legal or constitutional significance.

103 Parl Rec 3 July 1990, p 1271.

104 The enactment is an amendment to the Constitution Act 1989, XXI Statute, Section 76(2).

105 Amos and Walton's Introduction to French Law (2nd ed, Clarendon Press, Oxford, 1963) pp 47, 50, 54.

106 Cohn RJ Manual of German Law (2nd ed, Oceana Publ, Dobbs Ferry NY, 1968) Vol I; BGB s 80. 
In contrast the concept of the Holy Crown in Hungarian constitutional law reveals its unique character by the fact that the efficacy, "the objective reality", 107 the "life" of it is not necessarily connected with, and does not depend on, a ruling king. The Holy Crown has its own vibrant personality. It has developed - with remarkable dynamism and elasticity unattached to, and not dependant on, any human person as ruling monarch - into the supreme authority, a mystical and mythical being, a sovereign force surpassed by nobody. 108

The essential different is that the English (or British) Crown must always have a monarch whom it represents, while the Hungarian Holy Crown is a moral, specific personality in itself.

The mystique of the Holy Crown was and is more than a juristic fiction of constitutional law. It is the symbol of the nation which like religious faith the more explained and analysed the less understood. It is like belief in God. This mystical and mythical power did not perish during the more than forty years of Communist rule. Nothing illustrates it better than that the first freely elected Parliament of the democratic Republic restored, with a sizeable majority, the ancient coat of arms including the Holy Crown. By this gesture the representatives of the people gave official recognition to the Holy Crown as the emblem representing not a king but the state as an organised entity, the whole nation, and every ethnic Hungarian.

107 Amos \& Walton, above n 105, 48.

108 Eckhart, above n 13, 116; Nemeskürty, above n 64, 305. 


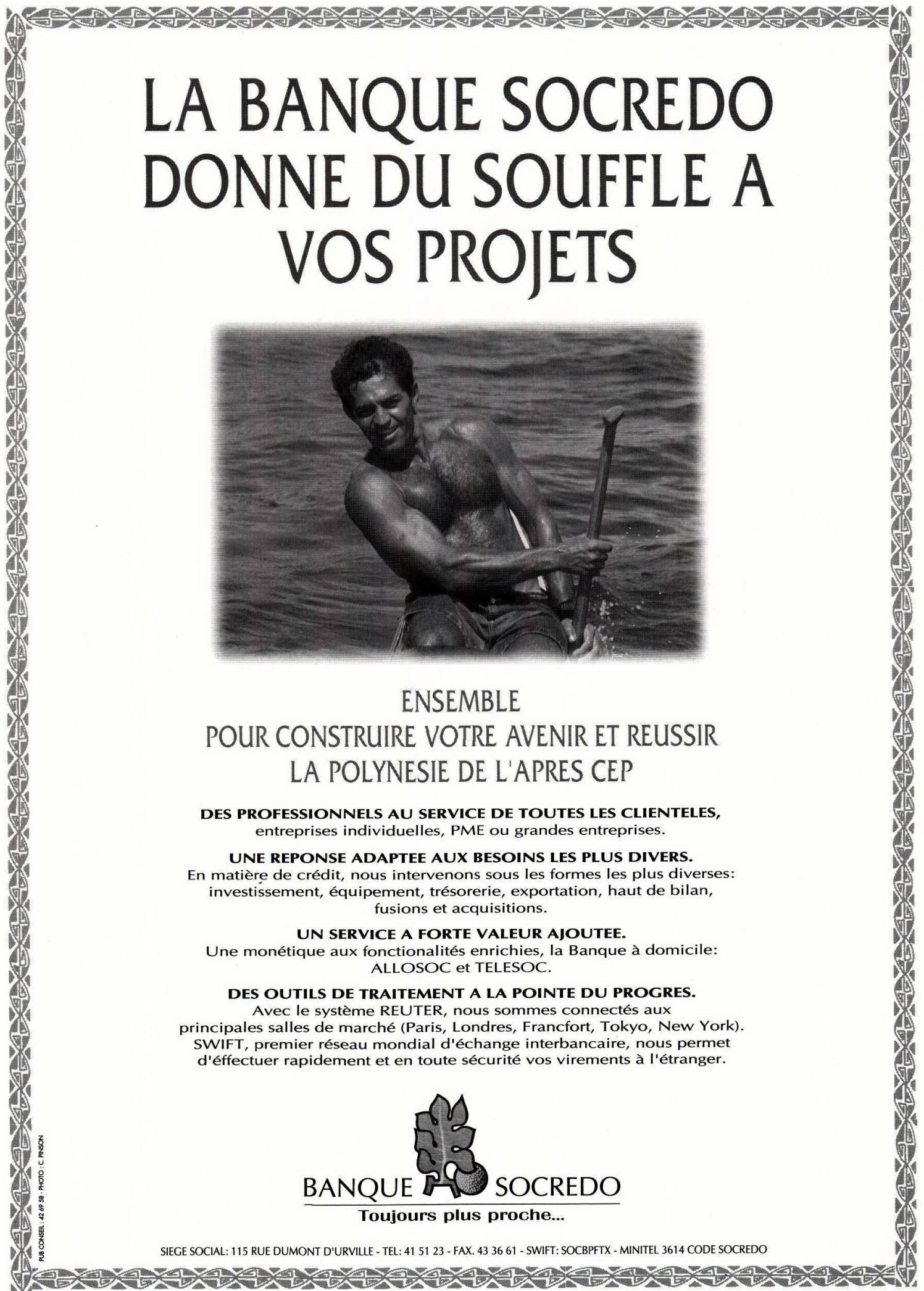

